RETORIKA: Jurnal Ilmu Bahasa, Vol. 1, No.2 Oktober 2015, 339-351

Available Online at http://ejournal.warmadewa.ac.id/index.php/jret

\title{
STRATEGY OF TRANSLATING GADGET BROCHURE
}

\begin{abstract}
Abstrak
Judul dari tulisan ini adalah strategi penterjemahan brosur gadget. Ada dua masalah yang dibahas dalam tulisan ini yaitu: (1) istilah yang ditemukan dalam brosur panduan manual dan padanan kata dalam bahasa Indonesia dan (2) strategi yang diterapkan dalam penterjemahan brosur gadget. Berdasarkan hasil analisis ditemukan bahwa istilah dan padanan kata dalam brosur gadget dapat diklasifikasikan berdasarkan: (1) Kata dasar atau kata majemuk dan frasa pembentuk istilah, (2) Kategori kata yang ditemukan yaitu kata benda dan kata kerja. Pola yang direkomendasikan untuk menentukan padanan kata yaitu, pure borrowing bukan adaptation borrowing. Konteks dari adaptation borrowing dalam hal ini berhubungan dengan ejaan dan pengucapan. Selain itu hasil penelitian dari tesis ini terdapat tujuh strategi yang diterapkan dalam penterjemahan brosur gadget yaitu: 'translation by more general word' (Superordinate) dengan kata lebih umum; 'translation by a more neutral/ expressive word' dengan kata netral/ekspresive; 'translation by cultural substitution' dengan pergantian kultur; 'translation by using loan word or loan word plus explanation' kata pinjaman atau kata pinjaman dengan penjelasan berhubungan, 'translation by paraphrase using related word' dengan para phrase berhubungan, 'translation by omission' dengan penghilangan, dan 'translation by illustration' dengan ilustrasi.
\end{abstract}

Kata Kunci: brosur gadget, strategi penterjemahan

\begin{abstract}
The title of this writing is strategy of translating gadget brochure. There were two problems discussed in this thesis, namely (1) terms found in the gadget manual book and its equivalence in Indonesia, (2) strategies applied in translating gadget brochure. Based on the analysis result, it was found that the terms and its equivalent words found in the gadget brochure were classified based on: 1) simple words or compound words and terminology forming phrase. 2) words category found are: noun and verb. The recommended pattern to determine the equivalent word was pure borrowing strategy, not adaptation borrowing strategy. The adaptation borrowing in this context was related to the spellings, the pronunciation or sound adaptation in the TL rather than adaptation for the cultural substitutes that conceptually mismatches with the standardized terminology in the SL. In addition, the result of the analysis that there were seven strategies found in gadget brochure, they were translation by more general word (Superordinate), translation by a more neutral/expressive word, translation by cultural substitution, translation by using loan word or loan word plus explanation, translation by paraphrase using related word, translation by omission and translation by illustration.
\end{abstract}

Keywords: Gadget brochure, Strategies of translation

\section{INTRODUCTION}

Discussing about translation, we need to understand grammar and structure of the two languages involved very well. Translation is known as a process of transferring meaning from one language into another. So many things can be translated such as novel, newspaper, and brochure. As a translator, when we translate brochure or advertisement from English language into Indonesian or Indonesian language into English, we will find difficulties and discrepancy of meaning. Recently, Gadgets have been primary need in society. They 
are very useful for the user. By having gadget, the user should know how to operate it. As we know that all gadgets came from outside our country therefore the user of manual guide are translated by using an International language. Not all the people are able to translate into target language in this case Indonesian. To avoid any discrepancy of meaning, therefore we need the strategy in translating it. Considering the condition above an analysis about strategy applied in translating gadget brochure is interesting than other translating analysis.

\section{CONCEPT AND THEORETICAL}

\section{FRAMEWORK}

\section{CONCEPT OF TRANSLATION}

The term of equivalence plays a major role in the translation process. The central problem in translation is to find out the target language translation equivalents. $\mathrm{Ni}$ da (1974:12) proposes two kinds of equivalents are the natural equivalent and the closest equivalent. Natural equivalent means the translation does not sound like a translation. While the closest equivalent means a translator must be able to find the closest meaning in the target language.

It is complicated process for a translator to look for the lexical equivalents between the source language and the receptor language. Larson (1998:169) states the receptor language is spoken by people from a culture which is often very different from the culture of those who speak the source language.

\section{Three Adequate Lexical Equivalents:}

In order to find the appropriate lexical equivalents, Larson (1998:169) proposes three matters that must be looked at in choosing adequate lexical equivalents:

(1).There will be concepts in the source text, which are known as and shared in the receptor language; however they will be translated by a non-literal equivalent.

(2).There will be concepts in the source language, which are unknown in the receptor language.

(3).There are lexical items in the text, which are the key terms that are important to the theme and development of the text which need special treatment.

\section{The Strategies of Translation}

These strategies are used for dealing with non-equivalence word, in this case those words which are considered to contain culture specific concept. Baker (1992:26-42) proposes eight strategies:

(1).Translation by a more general word (super ordinate).

This is one of the commonest strategies 
for dealing with many types of nonequivalence, particularly in the area of propositional meaning. It works equally in most, if not all, languages, since the hierarchical structure of semantic field is not language specific (Baker, 1992:26).

(2).Translation by a more natural or less expressive word.

Expressive meaning relates to the speaker feeling or attitude rather than to what word or utterance refer to (Baker, 1992: 13). While, neutral word means the word which has no reference meaning or no connotation. It is applied to avoid conveying the wrong expressive meaning. For example, English word that is translated into Japanese and back translated.

SL: The shamanic practices we have investigated are highly seen as an archaic mysticism.

BT: The shamanic behavior which we have been researching should rightly be considered as ancient mysticism (Baker, 1992:29).

(3).Translation by cultural substitution This strategy involves replacing a cultural a specific item or expression with a target language item which does not have the same propositional meaning but is likely to have similar impact on the target reader (Baker 1992:31). The main advantage of using this strategy is that it gives the reader a concept with which she or he can identify something familiar and a feeling. For example, an English Greek translation that is back translated into English:

SL: A well-known scientist (some say it was Bertrand Russell) once gave him a public lecture about astronomy.

BT: Alice in wonderland was once giving a lecture about astronomy. (Baker 1992: 31)

The translator decides that this is best achieved by introducing the reader to a character which is familiar and interesting rather than to a foreign character and steortype with which the reader may not identify.

(4).Translation using a loan word or loan word plus explanation

Based on Baker (1992: 34), this strategy is particularly common in dealing with culture-specific items, modern concepts, and buzzwords. Following the loan words with an explanation is very useful when the word in question is repeated several times in the text. Once explained, the loan word can be then used on its own; the reader can understand it and is not distracted by further lengthy explanations.

(5).Translation by paraphrase using a related word 
This strategy tends to be used when the concepts expressed by the source items is lexicalized in the target language but in a different form, and when the frequency with which a certain form is used in the source text is significantly higher than would be natural in the target language (Baker, 1992;37) in other words, by using this strategy, the focus of the translation, which is in paraphrase form is directly to the semantic meaning of the word without any influence form the contextual meaning and interpretative meaning.

(6). Translation by paraphrase using unrelated words

If the concept expressed by source item is not lexicalized at all in the target language, the paraphrase strategy can still be used in some contexts instead of a related word, the paraphrase may be based on modifying a super ordinate or simply on unpacking the meaning of the source item, particularly if the item in question is semantically complex (Baker, 1992: 39)
(7).Translation by omission

This strategy may sound rather drastic, but in fact it does no harm to omit translating a word or expression is not vital enough to the development of the text to justify distracting the reader with lengthy explanations, translator can be and often do simply omit translating the word or expression in question.

(7). Translation by illustration

This strategy is a useful option if the word which lacks an equivalent in the target language refers to a physical entity which can be illustrated, particularly if there are restrictions on space and if the text has remain short, concise and to the point.

\section{DISCUSSION}

\section{TERMS FORMED BY SIMPLE WORD}

The words that form term may be simple or complex. A simple word consists solely of a base, which cannot be broken into small units. Thus, based on the word concept the simple word forming terms consist of the whole data which can be presented such as:

Table 1: Terms formed by simple word

\begin{tabular}{|c|c|}
\hline SL & TL \\
\hline Caution & Awas \\
\hline Note & Catatan \\
\hline Content & Isi \\
\hline System & Sistem \\
\hline
\end{tabular}


From the data above, we can see that the data on the table are Simple words. In TL words "caution, note, content and system cannot be broken into small units. They consists solely a base. Then, in SL words 'awas, catatan, isi and sistem' are simple words. They cannot be broken into small units. They consists solely a base.

\section{Terms Formed by Compound Word and Phrase}

A compound word is a union of two or more words to convey a unit idea or special meaning that is not as clearly or quickly conveyed by separate words. Compound word maybe hyphenated, written open or written solid. Meanwhile, stated a phrase is a group of words which is grammatically equivalent to a single word, being able to occur in the same places as a word. The phrase type identified by the word class its head. Thus, a noun phrase contains a noun as Head, an adjective phrase contains an adjective as Head. Please find the data as below:

Table 2 : Terms formed by compound word and phrase

\begin{tabular}{|c|c|}
\hline SL & TL \\
\hline Touch screen & Layar Sentuh \\
\hline Volume Key & Tombol Volume \\
\hline Back Key & Tombol Kembali \\
\hline Front Camera & Kamera Depan \\
\hline Rear Camera & Kamera Belakang \\
\hline
\end{tabular}

From the data above, we can see that "Touch screen" in SL is compound word. It is a union of two words and conveys a unit idea. This compound word is written open. Thus, "Layar Sentuh" in TL is a phrase. It is a group of words which is grammatically equivalent to a single word, being able to occur in the same places as a word.

The data "Volume Key in SL is compound word. It is a union of two words and conveys a unit idea. This compound word is written open. Thus, "Tombol Volume" in TL TL is a phrase. It is a group of words which is grammatically equivalent to a sin- gle word, being able to occur in the same places as a word.

The data "Back Key" in SL is compound word. It is a union of two words and conveys a unit idea. This compound word is written open. Thus, "Tombol Kembali" in TL TL is phrase. It is a group of words which is grammatically equivalent to a single word, being able to occur in the same places as a word.

The data "Front Camera" in SL is compound word. It is a union of two words and conveys a unit idea. This compound word is written open. Thus, 
"KameraDepan" in TL is phrase. It is a group of words which is grammatically equivalent to a single word, being able to occur in the same places as a word.

The data "Rear Camera" in SL is compound word. It is a union of two words and conveys a unit idea. This compound word is written open. Thus, "KameraBelakang" in TL is phrase. It is a group of words which is grammatically equivalent to a single word, being able to occur in the same places as a word.

Classification of SL Term from the

\section{Structure}

From the generic structure, brochure consists of title, contain and contact person. The structures were analyzed based on combination of the data. The result found that all the users' gadget manual brochures have the similar structures. In this case, in user manual brochure the structure consist of introduction, getting started, content and safety information. In each part of the structures above found terms related to Gadget. The classification can be seen as follow:

1. Term found in Introduction Part

Table 3. Term With Simple Word.

\begin{tabular}{|c|c|c|}
\hline \multirow[t]{2}{*}{ No } & Simple Word & Equivalence \\
\hline & $\mathrm{SL}$ & TL \\
\hline 1 & Caution & Awas \\
\hline 2 & Note & Catatan \\
\hline 3 & Content & Isi \\
\hline 4 & Electronic & Elektronik \\
\hline 5 & System & Sistem \\
\hline 6 & Storage & Penyimpanan \\
\hline
\end{tabular}

Table 4. Term With Compound Word

\begin{tabular}{|c|c|c|}
\hline \multirow[t]{2}{*}{ No } & Compound Word & Equivalence \\
\hline & SL & $\mathrm{TL}$ \\
\hline 1 & Mobile Communication & Seluler \\
\hline 2 & Software & Perangkat Lunak \\
\hline 3 & Trademark & Merk Dagang \\
\hline 4 & Copyright & Hak Cipta \\
\hline
\end{tabular}


2) Term Found in "Getting Started"

Table 5. Term With Simple Word

\begin{tabular}{|l|l|l|}
\hline \multirow{2}{*}{ No } & \multicolumn{1}{|c|}{ Simple Word } & \multicolumn{1}{c|}{ Equivalence } \\
\cline { 2 - 4 } & \multicolumn{1}{|c|}{ SL } & \\
\hline 1 & Flash & Lampu kilat \\
\hline 2 & Speaker & Speaker \\
\hline
\end{tabular}

Table 6. Term With Compound Word

\begin{tabular}{|l|l|l|}
\hline \multirow{2}{*}{ No } & \multicolumn{1}{|c|}{ Compound Word } & \multicolumn{1}{c|}{ Equivalence } \\
\cline { 2 - 3 } & \multicolumn{1}{|c|}{ SL } & TL \\
\hline 1 & Front Camera & Kamera Depan \\
\hline 2 & Proximity sensor & Proximity Sensor \\
\hline 3 & Touch screen & Layar sentuh \\
\hline 4 & Home button & Tombol home \\
\hline
\end{tabular}

3) Term found in "Content"

Table 7. Term with simple word

\begin{tabular}{|l|l|l|}
\hline \multirow{2}{*}{ No } & \multicolumn{1}{|c|}{ Simple Word } & \multicolumn{1}{c|}{ Equivalence } \\
\cline { 2 - 4 } & \multicolumn{1}{|c|}{ SL } \\
\hline 1 & Device & Perangkat \\
\hline 2 & Screen & Layar \\
\hline
\end{tabular}

Table 8. Term With Compound Word

\begin{tabular}{|l|l|l|}
\hline \multirow{2}{*}{$\begin{array}{c}\text { N } \\
\text { o }\end{array}$} & \multicolumn{1}{|c|}{ Compound Word } & \multicolumn{1}{c|}{ Equivalence } \\
\cline { 2 - 3 } & \multicolumn{1}{|c|}{ SL } \\
\hline 1 & Mobile telephone & Ponsel \\
\hline 2 & Micro SIM & Micro SIM \\
\hline 3 & Power Button & TombolDaya \\
\hline
\end{tabular}

4) Term Found in "Safety Information"

Table 9: Term with Simple word

\begin{tabular}{|l|l|l|}
\hline \multirow{2}{*}{ No } & \multicolumn{1}{|c|}{ Simple Word } & \multicolumn{1}{c|}{ Equivalence } \\
\cline { 2 - 3 } & \multicolumn{1}{|c|}{ SL } \\
\hline 1 & Plugs & Kabel \\
\hline 2 & Disconnect & Mencabut \\
\hline 3 & Charger & Charger \\
\hline 4 & Battery & Baterai \\
\hline 5 & Accessories & Aksesori \\
\hline
\end{tabular}


RETORIKA: Jurnal Ilmu Bahasa, Vol. 1, No.2 Oktober 2015, 346

\begin{tabular}{|l|l|l|}
\hline \multirow{2}{*}{ No } & \multicolumn{1}{|c|}{ Compound Word SL } & \multicolumn{1}{|c|}{ Equivalence } \\
\cline { 2 - 3 } & \multicolumn{1}{|c|}{ TL } \\
\hline 1 & Mobile Device & Perangkat Seluler \\
\hline 2 & Power cord & Colokan listrik \\
\hline 3 & Frequency Signal & Sinyal Frekuensi \\
\hline 4 & Electronic Device & Perangkat Elektronik \\
\hline 5 & Audio Equipment & Peralatan Audio \\
\hline 6 & Radio Frequency & Frekuensi Radio \\
\hline 7 & Sound System & Sistem Suara \\
\hline 8 & Voice Mail & Pesan Suara \\
\hline 9 & Phone Number & Nomer Telepon \\
\hline 10 & Phone Cards & KartuTelepon \\
\hline 11 & Camera Flash & Kilat Kamera \\
\hline 12 & Touch Screen & Layar Sentuh \\
\hline
\end{tabular}

\section{Analysis Term from Word Categories}

All words belong to categories called word classes or parts of speech. Almost all lan- guages have the main word classes' noun, verb and adjective. The word category of the SL can be seen as follow:

Table 11 : Noun

\begin{tabular}{|l|l|l|}
\hline No & \multicolumn{1}{|c|}{ SL } & \\
\hline 1 & Warning & Peringatan \\
\hline 2 & Caution & Awas \\
\hline 3 & Note & Catatan \\
\hline 4 & Content & Isi \\
\hline 5 & Software & Perangkat Lunak \\
\hline 6 & Electronic & Elektronik \\
\hline 7 & System & Sistem \\
\hline 8 & Storage & Penyimpanan \\
\hline 9 & Trademark & Merek Dagang \\
\hline 10 & Copyright & Hak Cipta \\
\hline
\end{tabular}

Table 12: Verb

\begin{tabular}{|l|l|l|}
\hline No & \multicolumn{1}{|c|}{ SL } & \multicolumn{1}{c|}{ TL } \\
\hline 1 & Photocopying & Menggandakan \\
\hline 2 & Recording & Merekam \\
\hline 3 & Disconnect & Mencabut \\
\hline 4 & Install & Pasang \\
\hline
\end{tabular}




\section{Analysis of Terms by Procedure}

Baker (1992) explores the notion of equivalence at different levels: equivalence at word level, equivalence above word level, grammatical equivalence. These levels of equivalence are closely related to the translation process, including all different aspects of translation and hence putting together the linguistic and the communicative approach. A phenomenon of using the related words as equivalents in the TL occurs in all the related discussion data in this section. This matter occurs in two languages often do not have a matching of synonyms related to a given concept. In this context, between the SL and the TL in which one term in the SL provides at one word in the TL as equivalents that actually has only one word which would be the best for any one of these synonyms regarding to the SL concept. Such phenomenon in each pointed data in the following analysis can be seen respectively.

\section{Identification of Equivalence by Transla-} tion Procedure

Based on the sort out of forming terms in words and phrases of the terms above then, this part presents the identification of equivalent patterns through the translation procedures. The phenomenon found in the equivalent strategy by referring to the procedures of translation methodology identify the pattern that are mostly applied following procedures; 1) Pure Borrowing, 2) Adaptation Borrowing, 3) Literal Translation and 4) Adaptation for cultural substitute.

\section{The Equivalence Patterns by Borrowing}

As previously mentioned of the related reference the concept of borrowing is used to overcome a lacuna, usually a metalinguistic and it is the simplest of all translation methods. In connection with this study, borrowing procedure according to the standardized terminology is the proper equivalent strategy for the technical terms that stands for the concept like the gadget brochure terms. The forming terms in both pure borrowing and adaptation borrowing classification seem have the same and different characteristic deals with equivalent process.

In Indonesian borrowing that was known as absorption or 'penyerapan' in PUPI for mechanism of pure borrowing and adaptation borrowing had been set up according to the Indonesian 'Bahasa Indonesia" regulations or rules. Language aspects related to this absorption mechanism that need to be adapted such as; spellings, pronunciations or sounds, and suffixes in which each of them can be observed in the following equivalent process of the related data.

a) Equivalence through pure borrowing Pure borrowing in which the borrowed 


\section{Analysis of Terms by Procedure}

Baker (1992) explores the notion of equivalence at different levels: equivalence at word level, equivalence above word level, grammatical equivalence. These levels of equivalence are closely related to the translation process, including all different aspects of translation and hence putting together the linguistic and the communicative approach. A phenomenon of using the related words as equivalents in the TL occurs in all the related discussion data in this section. This matter occurs in two languages often do not have a matching of synonyms related to a given concept. In this context, between the SL and the TL in which one term in the SL provides at one word in the TL as equivalents that actually has only one word which would be the best for any one of these synonyms regarding to the SL concept. Such phenomenon in each pointed data in the following analysis can be seen respectively.

\section{Identification of Equivalence by Transla-} tion Procedure

Based on the sort out of forming terms in words and phrases of the terms above then, this part presents the identification of equivalent patterns through the translation procedures. The phenomenon found in the equivalent strategy by referring to the procedures of translation methodology identify the pattern that are mostly applied following procedures; 1) Pure Borrowing, 2) Adaptation Borrowing, 3) Literal Translation and 4) Adaptation for cultural substitute.

\section{The Equivalence Patterns by Borrowing}

As previously mentioned of the related reference the concept of borrowing is used to overcome a lacuna, usually a metalinguistic and it is the simplest of all translation methods. In connection with this study, borrowing procedure according to the standardized terminology is the proper equivalent strategy for the technical terms that stands for the concept like the gadget brochure terms. The forming terms in both pure borrowing and adaptation borrowing classification seem have the same and different characteristic deals with equivalent process.

In Indonesian borrowing that was known as absorption or 'penyerapan' in PUPI for mechanism of pure borrowing and adaptation borrowing had been set up according to the Indonesian 'Bahasa Indonesia" regulations or rules. Language aspects related to this absorption mechanism that need to be adapted such as; spellings, pronunciations or sounds, and suffixes in which each of them can be observed in the following equivalent process of the related data.

a) Equivalence through pure borrowing Pure borrowing in which the borrowed 
word without going through the morphological adaptation and each of the word elements were preserved in the TL spelling.
Most of such data were obtainable in word forming terms, such as:

Table 13. Equivalence Through Pure Borrowing

\begin{tabular}{|l|l|l|}
\hline No & SL & TL \\
\hline 1 & Sensor & Sensor \\
\hline 2 & Earpiece & Earpiece \\
\hline 3 & Speaker & Speaker \\
\hline 4 & Earphone & Earphone \\
\hline 5 & Volume & Volume \\
\hline 6 & Headset & Headset \\
\hline
\end{tabular}

Linguistically, morphological adaptation could be conducted in adaptation borrowing for the technical terms equivalence. Otherwise, the pure borrowing is considered to be better like the related terms above.

b) Equivalence through the borrowing of sound and spelling adaptation

The category of borrowing such as the following terms in which the sounds are adapted in accordance with the TL regulation as stated in PUPI. Most of such categories are obtainable in word forming terms, such as:

Table 14: Equivalence Through the Borrowing of Sound and Spelling Adaptation

\begin{tabular}{|c|c|c|}
\hline No & SL & $\mathrm{TL}$ \\
\hline 1 & Electronic & Elektronik \\
\hline 2 & System & Sistem \\
\hline 3 & Microphone & Mikrofon \\
\hline 4 & Telephones & Telepon \\
\hline 5 & Battery & Baterai \\
\hline
\end{tabular}

Table 15: Sensor

\begin{tabular}{|l|l|l|}
\hline SL & SL Concept & TL \\
\hline Sensor & Is a transducer whose purpose is o sense some & Sensor \\
& characteristic of it's environments. It detects & \\
& events or changes in quantities and provides a & \\
& corresponding output, generally as an electrical \\
& or optical signal. & \\
\hline
\end{tabular}

The word "sensor" in the TL as the equivalence for "sensor" in the SL, in this case accidentally it is the same in form and meaning, and in the equivalence process it can be said as equivalence at the same word level. Based on this analysis "sensor" in 
this context in the TL would be the best choice and acceptable in expressing and covering the idea of "sensor" as a term. This word is originally loaned in target language. The SL word "Sensor" has concept in the SL as a transducer whose purpose is osense some characteristic of its environs. It detects events or changes in quantities and provides a corresponding output, generally as an electrical or optical signal. The nearest meaning in the TL by loan word concept makes the word "Sensor" in SL become "Sensor" in TL.

\section{CONCLUSION}

(1).Terms with their equivalence are classified based on the simple words or compound word of forming terms and phrase of forming terms. In addition, two (2) words categories found namely "noun and verb". The pattern is recommended for the adequacy equivalence strategy namely pure borrowing instead of adaptation borrowing with referring to each of the term concept through the meaning componential analysis. The adaptation borrowing in this context is related to the spellings, the pronunciation or sound adaptation in the TL rather than adaptation for the cultural substitutes that conceptually mismatches with the standardized terminology in the SL.
(2).There are seven strategies found in analysis gadget brochure, they are translation by more general word (Superordinate), translation by a more neutral/expressive word, translation by cultural substitution, translation by using loan word or loan word plus explanation, translation by paraphrase using related word, translation by omission and translation by illustration.

\section{ACKNOWLEDGMENTS}

First of all, I would like to express my deepest gratitude to Ida Sang Hyang Widhi Wasa, the Supreme God for His blessing. I believe without His blessing, this thesis cannot be accomplished in proper time.

In this opportunity, I would like to express my gratitude to Prof. Dr. Ida Bagus Putra Yadnya, MA and Dr. I Nyoman Kardana, M.Hum., as my first and second advisor for their supports and advices in writing this thesis. I also would like to express my gratitude to Dr. Ni Wayan Kasni, M.Hum., as the head of Master Degree Program in Linguistics Study of Warmadewa University, Drs. I Ketut Sudrama, M.Hum., as the Secretary of Master Degree Program in Linguistics Study of Warmadewa University and all lecturers of Master Degree Program in Linguistics Study of Warmadewa University. 
I would like to express my special thank to my beloved parents for their material and moral motivation, to my beloved Rara for her great help and support that I needed during writing this thesis.

\section{BIBLIOGRAPHY}

Alwi, Hasan, dkk. 1998. Tata Bahasa Indonesia. Jakarta: BalaiPustaka

Baker, Mona. 1992. In other words: a coursebook on translation. London and New York: Routledge.

Bell, R.T. 1991. Translation and Translation Theory and Practice. New York: Longman Inc.

Catford A, J. 1965. A Linguistic Theory of Translation. London: Oxford University Press. Larson, Mildred L. Meaning Based Translation: A Guide to CrossLanguageEquivalence. New York: University Press of America

Hornby, A.S. 1994. Oxford Advance Learners Dictionary. London: Oxford University Press.

Kridalaksana, I.M. 2007. "An Analysis on Translating Strategies of AnimalImagelMetaphors found in the novel 'A Stranger in the mirror' by Sydney Sheldon into Indonesian". [thesis]. Denpasar.Udayana University

Larson, Mildred L. 1998. Meaning Based Translation: A Guide to Cross-Language Equivalence. New York: University Press of America.

Leech, G. 1992. English Grammar. London: Penguin English

Newmark, Peter. 1981. A Text Book Of Translation. London: Prentice-Hall.

Nida, Eugene A. 1975. Language Structure and Translation. Standard, California: Standard University Press

Nida, Eugene A. 2000. Principle of Correspondence.In: Venuti. Lawrence, 2000. The translation study reader, New York: Routledge

Nida, E. A \& Taber, C. R 1982.The Theory and Practice of Translation. Leiden: E.J. Brill

Ordudary, Mahmoud. 2007. "Translation Procedures Strategies and Methods". Translation journal. Volume II.No. 2. Cited
(April, $\left.21^{\text {st }} 2008\right)$ available from: URL: http: //accurapid.com/journal/

Pinchuck, Isadore. 1977. Scientific and technical translation. London: Andre Deutsch Limited.

Puspani, Ida Ayu Made. 2003. The Semantic Features of the Terms Related Balinese Culture in the novel: SukreniGadis Bali and Their Translation in The Rape of Sukreni. (Master Thesis). Denpasar.Udayana University.

PutriWirastuti, I GustiAgung. 2006. "Strategies of Translating English Idiom in The Novel Lord of The Rings "The Two Tower" [thesis]. Denpasar: Udayana University.

Putra Yadnya, I. B 2004.Pemadanan Makna Berkonteks Budaya: Sebuah kajian terjemahan Indonesia - Bahasa Inggris [disertasi]. Denpasar: UniversitasUdayana.

Said Marshadi.2003 Strategi untuk konsep yang tidak dikenal dalam Bahasa sasaran. Surakarta. UNS.

Suasti, Ketut. 2004. "Indonesian Labor Terms and their translation in English". [thesis]. Denpasar. Udayana University.

Sudariyanto. 1993. Metodedan Aneka TeknikAnalisisBahasa. Jakarta: Duta Wacana University Press.

Sudrama, Ketut. 2003. "Strategies for Translating into Indonesian English Methaporin novel 'Master of the game' by Sidney Sheldon" [thesis]. Denpasar: Udayana University.

Swan, M. 1980. Practical English Usage.Oxford: Oxford University Press.

Thomson, A.J and A.V Martinet. 1986. A practical English Grammar. Oxford: Oxford University Press.

Vinay and Darbalnet, 1958.Methodology of Translation in Venuty, Lawrence, 2000.The Translation Studies Reader.London Routledge.

Wikipedia. Concept Terminology. Available from http:/en.wikipedia.org/wiki/ Technical_Terminology. Accessed/12/2015

Wikipedia. Concept. Available from http:// en.wikipedia.org/wiki/wiki.concept. accesed.1/1/2015

Wikipedia.Istilah Internet Indonesia. 